\title{
Congressional gridlock sinks US science bills
}

Washington. Legislation central to the science, technology and environmental policies of the Clinton administration is set to be lost, much of it probably for good, when the US Congress breaks up at the end of this week for November's elections.

The failure of key bills such as the would authorize new technology programmes, including an ambitious research programme for the information super-highway - as well as a tranche of proposed environmental legislation, is partly the result of the Republican party's decision to use its 45 votes in the Senate to block as much as it possibly can in the run-up to November's poll.

But the poor legislative track record of the 103rd Congress is also being blamed on the ineffectual backing the administration has given to its own political agenda, as well as to a fragmented committee structure that makes it difficult for science and technology measures to pass both the House of Repre-

Congressman George Brown (Democrat, California), chairman of the House of Representatives Science, Space and Technology Committee, says he is "bitterly disappointed" with the progress that his comprogramme.

Science bills that have failed to advance National Competitiveness Act - which sentatives and the Senate. mittee was able to make with its legislative

during the session include a fusion and highenergy physics act (see Nature 370,5; 1994), which, among other things, would have opened the way for US participation in the Large Hadron Collider at the European Laboratory for Particle Physics (CERN). The bill passed in the House of Representatives, but not in the Senate, where Senator Bennett Johnston (Democrat, Louisiana) said it should not proceed until the Congress clarifies its approach to fusion research.

The two houses have also been unable to agree on new authorizing legislation for the National Science Foundation (NSF). Like other agencies, the NSF will now have to function without such legislation, taking its direction instead from the appropriations subcommittees that provide its budget.

This week, congressional staff were still working on a reauthorization bill for the National Aeronautics and Space Administration (NASA) which, they say, has a reasonable chance of being passed into law before the session ends.

But other science legislation, including bills authorizing the activities of Environmental Protection Agency (EPA) research, for the possible consolidation of Department of Energy laboratories, for improved risk-assessment processes at the EPA, and for the creation of a National Biological Survey (see below), will not pass through this year's congressional gridlock.

\section{Biological survey still left in limbo}

Washington. Despite Congress' failure (see above) to pass legislation officially creating a new National Biological Survey (NBS), the survey plans to continue operating within the Department of Interior under the authority of Bruce Babbitt, the interior secretary.

Meanwhile, Ronald Pulliam, the director of NBS, has been telling audiences that the name "survey" has become something of a political liability, and has been stressing the agency's broader role in providing scientific advice on environmental matters to decision-makers.

Following unexpected attacks from supporters of anti-environmental lobbyists in the House of Representatives last year (see Nature 367,$400 ; 1994$ ), the Clinton administration held back from pushing for what NBS officials call "organic" authorizing legislation.

The bill will now have to be reintroduced in the next Congress; without the legal foundation that the bill is intended to provide, NBS supporters fear the agency could be killed by an unfriendly future administration.

Meanwhile, Congress last week approved with little debate $\$ 176$ million for next year's NBS budget in the Department of Interior. The only opposition came in the form of two amendments. One requires NBS researchers to get written permission from landowners before conducting any new surveys on their property, the second prevents the agency from hiring volunteers.

Although the latter restriction could pose a serious obstacle, agency officials may be able to work around it by interpreting the restriction to mean only new volunteers. Volunteers working on existing projects for the Fish and Wildlife Service, from which most of the survey staff were drawn, would therefore still be allowed.

The 1995 budget appropriation, which matches this year's level, allows the agency to get on with the task of setting up pilot research projects as well as strengthening ties with other federal agencies. Last week the NBS signed an agreement to share ecological and biological data with the Environmental Protection Agency and to coordinate the two agencies' research activities, including joint field data collection and integrated ecological risk assessments.

Tony Reichhardt
The Clinton administration fought hard last week to salvage a version of the $\mathrm{Na}$ tional Competitiveness Act that would pass both houses, but seemed likely to fail. The act contains the research and development programmes to enable the construction of the 'information superhighway'. Legislation on telecommunications regulation, which is considered far more critical to the

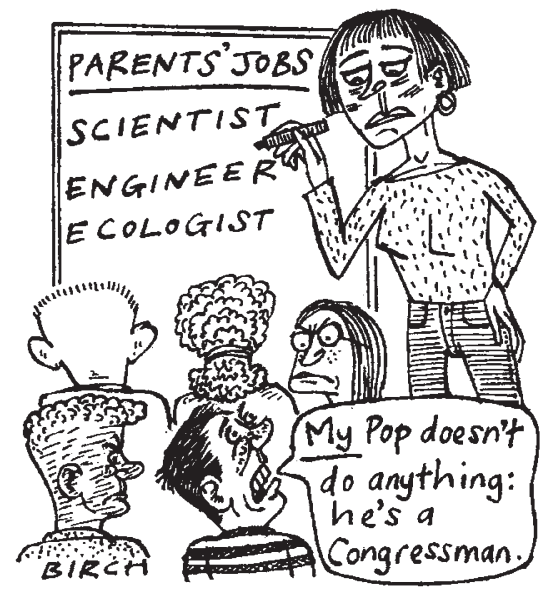

superhighway's prospects, was withdrawn last week by a key sponsor, Senator Ernest Hollings (Democrat, South Carolina).

On environmental policy, the setbacks to the administration have been even more severe. Green lobbyists have been stunned by the realization that, even with Clinton and vice-president $\mathrm{Al}$ Gore in power, and large Democrat majorities in both houses, they have got nothing through the Congress this year.

The Safe Drinking Water Act, the Clean Water Act, legislation to reinvigorate the Superfund clean-up scheme, and the overdue reauthorization of the Endangered Species Act all seem about to fail. Despite a fierce lastminute push by its industrial and environmental supporters, the Senate is also unlikely to ratify before the adjornment the Biodiversity Treaty agreed at the Earth Summit in Rio de Janeiro in 1992.

Some of the science bills are politically neutral and may be revived next year. But the environmental bills are highly contentious, and their failure this year has left Washington's large environmental lobby in grim mood, particularly as it expects the incoming Congress to be less keen on environmental regulation and more supportive of landowners' rights.

The legislative inaction is leading those who work to influence the law-making process to reopen the question what is Congress for? The voters are expected to answer in their own way on 8 November by rejecting many of the 435 congressmen and 33 senators who are standing for re-election.

Colin Macilwain 